\title{
KOPING STRESPADA NARAPIDANA REMAJA (STUDI KASUS DI LEMBAGA PEMBINAAN KHUSUS ANAK KELAS II KOTA KENDARI)
}

\author{
Siti Rahmi Utari ${ }^{1}$, Waode Suarni ${ }^{2}$, Aspin ${ }^{3}$. \\ Program Studi Psikologi \\ Fakultas Keguruan dan Ilmu Pendidikan, Universitas Halu Oleo \\ Email : strahmi18@gmail.com
}

\begin{abstract}
ABSTRAK
Lembaga pembinaan khusus anak (LPKA) adalah suatu tempat untuk melakukan pembinaan terhadap narapidana remaja dengan tujuan ketika remaja kembali ke masyarakat dapat menjadi lebih baik dari sebelumnya. Keadaan yang sangat berbeda antara di luar dan di dalam lingkungan LPKA membuat narapidana remaja menjadi tidak nyaman sehingga menimbulkan stres (stressor). Setiap narapidana remaja dapat memiliki strategi koping tertentu sehingga akan dapat menyesuaikan diri. Sedangkan narapidana remaja yang tidak memiliki strategi koping stres akan tidak mudah untuk menyesuaikan diri dan akan mudah mengalami stres. Penelitian ini bertujuan untuk mendeskripsikan strategi koping stres yang digunakan oleh narapidana remaja di LPKA Kelas II Kota Kendari dalam menghadapi dunia penjara. Metode yang digunakan adalah metode kualitatif dengan desain penelitian studi kasus. Subjek dalam penelitian ini berjumlah 3 orang narapidana remaja yang diambil dengan teknik purposive sampling dan 6 orang informan pendukung. Analisa data yang digunakan adalah narasi deskriptif. Metode pengumpulan data diperoleh melalui wawancara dan observasi. Berdasarkan hasil penelitian menunjukan bahwa strategi koping stres yang digunakan narapidana remaja di LPKA Kelas II Kota Kendari adalah stratregi koping yang berorientasi pada emosi atau emotion focused coping. Pemilihan strategi koping yang berorientasi pada emosi didasarkan karena narapidana remaja ingin melupakan hukuman yang sedang terjadi dengan melakukan berbagai kegiatan seperti bemain gitar, menontontelevisi,berkumpulbersamanarapidanalain, tidur, dan beribadah.
\end{abstract}

Kata kunci: narapidana remaja, lembaga pembinaan khusus anak, koping stres.

\begin{abstract}
Children Correction Institution (Lembaga Pembinaan Khusus Anak - LPKA) is an institution that provides guidance for adolescent inmates in order to help them to become better individuals when they return to the society. The different conditions between in and out of LPKA could make the adolescent inmates feel uncomfortable which further could trigger stresses (stressor).Every adolescent inmate may has a certain strategy to cope with his stress they experience. Those with no stress coping strategy might not be easy to adjust to his/her environment which furher makes him/her easily stressed.The purpose of this study is to have a clear description of stress coping strategies used by adolecent inmates in LPKA Level II Kendari in their adjustment to their daily life in prison.Three purposely sampled adoslescent inmates had participated in this case study. In addition, there are also six supporting informants. The data collected utilizing interview and observation techniques then were analyzed through descriptive naration.This study results show that emotion-focused orientation is the strategy that most frequently used by adolescent inmates to cope with stresses they experience. The reason behind this preference is because they want to just forget about the inprisonment they are serving at the moment. Playing guitar, watching $\mathrm{t}$, beeing and chatting with other inmates, sleeping, and doing religious rituals are among activities they had frequently doing to cope with their stresses.
\end{abstract}

Key words: stress-coping, adolescent inmate, children correctional institution 


\section{Pendahuluan}

Sejatinya semua orang tua menginginkan anaknya tumbuh menjadi remaja yang sehat, cerdas, dan terhindar dari pergaulan buruk serta tidak terjerumus dalam tindak pidana. Pada masa remaja terjadi suatu proses pencarian jati diri yang mendorong remaja untuk memiliki rasa keingintahuan yang tinggi, ingin tampil menonjol dan ingin diakui. Rasa keingintahuan yang tinggi tersebut terkadang menjadi penyebab remaja melakukan berbagai macam perilaku yang menyimpang karena mereka menganggap bahwa mereka sama seperti orang dewasa.

Di zaman sekarang banyak remaja yang berpikiran bahwa tidak nakal maka tidak gaul. Hurlock (1999) menyatakan bahwa kenakalan remaja adalah tindakan pelanggaran hukum yang dilakukan oleh remaja, dimana tindakan tersebut dapat membuat seseorang atau remaja yang melakukannya masuk ke dalam penjara. Seorang remaja yang melakukan pelanggaran hukum pidana dan terjadi pemidanaan akan disebut sebagai narapidana remaja.

Harsono (dalam Lubis 1997), mengatakan bahwa narapidana adalah seseorang yang dijatuhkan vonis bersalah oleh hakim dan harus menjalani hukuman. Narapidana adalah seseorang yang melakukan tindakan pidana dan harus menjalani hukuman berupa hilangnya kemerdekaan di Lembaga Pemasyarakatan. Di kota Kendari terdapat 3 macam Lembaga Pemasyarakatan (Lapas) yaitu Lapas anak, Lapas wanita, dan Lapas dewasa. Narapidana remaja akan menjalani hukuman di Lembaga Pembinaan Khusus Anak (LPKA).

Lembaga Pembinaan Khusus Anak (LPKA) atau Lapas Anak adalah suatu tempat untuk melakukan pembinaan terhadap narapidana remaja dengan tujuan ketika remaja kembali ke masyarakat dapat menjadi lebih baik dari sebelumnya. Berdasarkan data yang diperoleh dari LPKA Kota Kendari bahwa jumlah narapidana remaja pada tahun 2017 sebanyak 72 orang, pada tahun 2018 sebanyak 49 orang, dan pada tahun 2019 bulan Januari sebanyak 10 orang.

Narapidana remaja yang menjalani proses pembinaan berada dalam rentang usia 14-17 tahun, dengan berbagai macam kasus seperti kesusilaan, pemerkosaan, pembunuhan, pencurian, lakalantas, senjata tajam, perusakan, narkoba, dan penganiayaan. Faktor-faktor yang menyebabkan para narapidana remaja melakukan kejahatan yaitu karena tidak dapat mengendalikan emosi sehingga melakukan tindakan agresivitas, faktor ekonomi, faktor lingkungan dan pergaulan, dan kurangnya perhatian dari orang tua.

LPKA Kota Kendari hanya menyediakan fasilitas berupa ruang belajar, mushola, perpustakaan mini, kamar mandi luar, dan satu wisma yang digunakan untuk tidur sehingga para narapidana remaja tidak memiliki kamar tidur khusus, hal ini menyebabkan para narapidana remaja tersebut tidak dapat memiliki ruang untuk menyimpan barangbarang yang bersifat privasi dan memiliki tidur yang kurang berkualitas dikarenakan suhu ruangan yang panas dan suasana yang gaduh.

LPKA kota Kendari juga diberikan berbagai kegiatan pembinaan kepada narapidana, seperti kegiatan rohani, pendidikan formal, olahraga, dan berbagai keterampilan yang dapat dikembangkan berdasarkan kemampuan dan bakat masing-masing remaja. Keterbatasan ruang bergerak, dan kegiatan yang terbatas dan monoton membuat narapidana remaja merasa terkurung dan tidaknyaman. Keterbatasan dan ketidaknyamanan tersebut membuat para narapidana remaja menjadi tertekan hingga merasakan stres.

Remaja dengan status narapidana yang berada di Lembaga Pembinaan Khusus Anak (LPKA) akan mengalami banyak perubahan hidup diantaranya adalah hidup terpisah dari orang tua, keluarga, teman, dan masyarakat, hilangnya kebebasan untuk menjalani kehidupan sebagaimana keinginannya, 
hak-hak yang semakin terbatas, dan memperoleh gelar sebagai penjahat. Selain itu, mereka harus hidup di antara narapidana lain dengan kasus yang berbeda tentunya akan menyebabkan seseorang merasa cemas dan frustasi yang berujung pada timbulnya stres.

Lazarus (dalam Matthieuw \& Ivanoff, 2006) menyatakan bahwa stres terjadi jika seseorang mengalami tuntutan yang melampaui sumber daya yang dimilikinya untuk melakukan penyesuaian diri, hal ini berarti bahwa kondisi stres terjadi jika adanya ketidakseimbangan antara tuntutan dan kemampuan. Sumber stres dapat berasal dari dalam diri dan di luar diri. Terjadinya stres karena stresor tersebut dirasakan dan dipersepsikan oleh individu sebagai ancaman sehingga menimbulkan kecemasan yang merupakan tanda umum dan awal dari gangguan kesehatan fisik dan psikologis.

Setiap orang mempunyai cara untuk mengatasi stres yang disebut dengan koping stres. Koping stres merupakan kemampuan seseorang dalam mengatasi situasi stressful atau tuntutan-tuntutan yang tidak bisa diselesaikan oleh seseorang individu yang dialaminya dalam kehidupan sehari-hari, tetapi tidak semua individu memiliki koping stres. Individu yang memiliki koping stress dapat beradaptasi dengan lingkungan baru dan dapat dengan mudah melewati fase stresnya, sedangkan individu yang tidak memiliki koping stres yang baik akan susah beradaptasi dengan lingkungan dan membuatnya menjadi tertekan dan stres.

Smet (dalam Musradinur, 2016) mengatakan cara melakukan koping stres individu yang satu dengan yang lainnya tidaklah sama, hal ini dipengaruhi beberapa faktor diantaranya adalah strategi koping stres yang digunakan, variabel dalam kondisi individu yang termasuk umur, jenis kelamin, temperamen, faktor genetik, inteligensi, pendidikan, suku, kebudayaan, status ekonomi dan kondisi fisik, karakteristik kepribadian, keadaan emosional, dukungan sosial yang dirasakan atau didapatkan individu, dan kontrol pribadi yang dirasakan.

Narapidana dewasa memiliki koping stres yang lebih baik dibandingkan dengan narapidana remaja hal ini dikarenakan pada orang dewasa sudah memiliki banyak pengalaman hidup dan pengalaman menghadapi berbagai situasi yang membuat stres. Koping stres pada orang dewasa juga jauh lebih baik karena keadaan emosional yang sudah stabil sehingga sudah lebih baik dalam mengontrol diri. Sementara masa remaja masih dalam proses pencarian jati diri dan keadaan emosional yang masih sangat labil sehingga menyebabkan koping stres remaja tidak sebaik orang dewasa.

Berdasarkan penjelasan di atas, bahwa kehidupan yang dirasakan oleh remaja saat berada di dalam lembaga pembinaan dan di luar sangatlah berbeda. Kehidupan di dalam lembaga pembinaan menyebabkan remaja menjadi sangat terkekang dan menjadi frustasi sehingga menyebabkan stres. Pemikiran para remaja mengenai nasib mereka ketika keluar dari lembaga pembinaan yang akan dicap sebagai penjahat di kalangan masyarakat juga menyebabkan mereka semakin stres. Seharusnya walaupun narapidana remaja tersebut berada di dalam kondisi terpenjara yang menyebabkan timbulnya stres, kesehatan mental mereka harus tetap terjaga agar ketika mereka kembali ke dalam lingkungan masyarakat mereka bisa menjadi masyarakat yang biasa seperti yang lainnya. Remaja yang memiliki koping stres yang baik akan mampu menghadapi lingkungan baru dan tekanan yang didapatnya, tetapi berbeda dengan remaja yang tidak dapat melakukan adaptasi ataupun koping stres. Berdasarkan penjelasan tersebut maka peneliti tertarik untuk mengangkat judul "Koping Stres Narapidana Remaja Studi Kasus Di Lembaga Pembinaan Khusus Anak (LPKA) Kelas II Kota Kendari”. 


\section{Rumusan Masalah}

Berdasarkan latar belakang diatas maka peneliti merumuskan masalah 'Bagaimanakah koping stresnarapidana remaja di Lembaga Pembinaan Khusus Anak (LPKA) Kelas II Kota Kendari?'

\section{Tujuan Penelitian}

Tujuan dari penelitian ini adalah untuk mengetahui koping stress narapidana remaja di Lembaga Pembinaan Khusus Anak (LPKA) Kelas II Kota Kendari.

\section{Manfaat Penelitian}

\section{Manfaat Teoritis}

Penelitian ini secara teoritis diharapkan dapat memberikan sumbangsih pemikiran berkaitan dengan koping stress narapidana remaja dan dapat dijadikan sebagai salah satu acuan untuk melakukan penelitian selanjutnya, serta diharapkan dapat melengkapi temuan-temuan yang berhubungan dengan koping stresnarapidana remaja.

2. Manfaat Praktis

a. Bagi peneliti selanjutnya

Bagi peneliti selanjutnya, penelitian ini diharapkan dapat menambah wawasan dan memberi pengetahuan tentang koping stress narapidana remaja.

b. Bagi Lembaga Pembinaan Khusus Anak Kota Kendari

Bagi pihak Lembaga Pembinaan Khusus Anak Kota Kendari, diharapkan penelitian ini dapat memberikan informasi mengenai gambaran koping stress narapidana remaja sehingga dapat melakukan pembinaan yang tepat agar para narapidana tidak terlalu merasa stres dan setelah bebas dari masa hukuman dapat menjadi pribadi yang lebih baik.

c. Bagi Masyarakat

Bagi masyarakat diharapkan dapat memberikan informasi mengenai gambaran koping stress narapidana remaja agar ketika mereka bebas masyarakat tidak mengucilkannya.

d. Bagi Narapidana Remaja

Bagi narapidana remaja diharapkan dapat memberikan informasi mengenai gambaran koping stress agar mampu mengelola stres yang dialaminya.

\section{Metode Penelitian}

Jenis penelitian ini merupakan penelitian kualitatif dengan menggunakan desain penelitian studi kasus. Subjek dalam penelitian ini berjumlah 3 orang, teknik pengambilan subjek dalam penelitian ini menggunakan purposive sampling. Kriteria subjek dalam penelitian ini adalah narapidana yang terdapat di LPKA Kelas II Kota Kendari dan berusia remaja. Analisis data hasil penelitian dilakukan dengan analisis deskriptif narasi.

\section{Hasil Dan Pembahasan \\ Latar Belakang Permasalahan}

Berdasarkan hasil penelitian dapat disimpulkan bahwa subjek $\mathrm{G}$ melakukan pembunuhan karena tidak dapat mengontrol diri yang menyebabkan subjek tidak dapat menahan emosinya dan melampiaskannya dengan cara agresif (membunuh). Selain karena tidak dapat mengontrol diri, subjek $\mathrm{G}$ juga berperilaku agresif karena kurangnya perhatian orang tua subjek mengenai aktivitas yang dilakukan subjek dan subjek kurang mendapatkan kasih sayang dari kedua orang tuanya. Faktor pengaruh teman sebaya juga ikut berpengaruh karena perilaku agresif yang dilakukan subjek dipelajari melalui teman-temannya, dan subjek sering ikut tawuran bersama temantemannya. Hal ini menyebabkan subjek terbiasa melakukan tindakan agresif seperti melukai orang lain.

Subjek R melakukan pembunuhan karena faktor yang sama yaitu tidak dapat mengontrol diri yang menyebabkan subjek tidak dapat menahan emosinya dan melampiaskannya dengan cara agresif (membunuh). Selain itu karena orang tua 
subjek yang terlalu memberi kebebasan terhadap subjek sehingga kurangnya perhatian orang tua subjek mengenai aktivitas yang dilakukan subjek.

Berdasarkan hasil penelitian yang dilakukan oleh Sentana dan Kemala (2017) menunjukkan bahwa terdapat hubungan yang negatif antara agresivitas dan kontrol diri. Hubungan yang negatif tersebut menunjukkan bahwa semakin tinggi kontrol diri pada remaja maka akan semakin rendah pula agresivitas remaja. Menurut Ghufron dan Ghufron dan Risnawati (2011) kontrol diri dipengaruhi oleh faktor internal dan eksternal. Faktor internal yang mempengaruhi kontrol diri adalah usia, dan faktor eksternal yang mempengaruhi kontrol diri iantaranya adalah lingkungan keluarga.

Adanya hubungan antara agresivitas dan kontrol diri juga ada pada subjek Ro yang menggunakan narkoba karena faktor pengaruh teman sebaya, subjek mengenal narkoba melalui temannya. Selain karena faktor pengaruh sebaya, subjek Ro juga menggunakan narkoba karena kurangnya perhatian orang tua subjek mengenai aktivitas yang dilakukan subjek dan orang tua subjek tidak memperhatikan lingkungan pertemanan subjek.

Penjelasan di atas dapat ditarik kesimpulan bahwa faktor yang menyebabkan subjek $\mathrm{G}$ dan $\mathrm{R}$ melakukan pembunuhan dan subjek Ro yang menggunakan narkotika yaitu kurangnya kontrol diri, pengaruh teman sebaya, dan kurangnya perhatian orang tua kepada aktivitas anak.

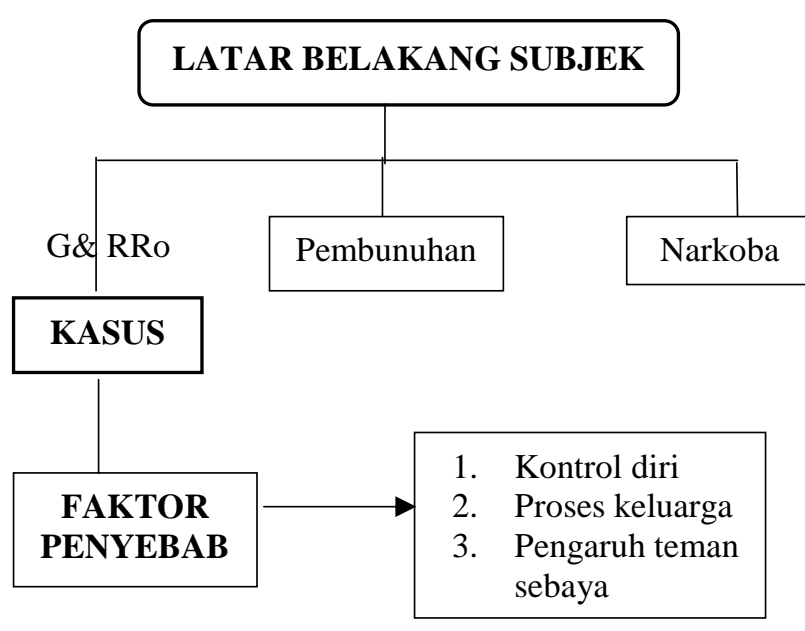

Gambar 1. Latar belakang subjek

\section{Stres}

Hal yang menjadi sumber stres (stressor) yang dialami oleh ketiga subjek penelitian yaitu adanya konflik atau permasalahan antara gaya hidup yang diinginkan oleh subjek seperti ingin hidup bebas dan berperilaku sesuai keinginannya seperti sebelum masuk di LPKA, tetapi kenyataannya lingkungan di LPKA memiliki banyak aturan yang menyebabkan para subjek tidak dapat hidup dan berperilaku sesuai dengan keinginan mereka. Lamanya vonis hukuman yang mereka terima juga menjadi salah satu penyebab stres yang dialami subjek. Selain karena konflik perbedaan lingkungan yang dijalani, subjek juga merasa stres karena mereka jauh dari keluarga sehingga mereka sering merasa rindu dengan keluarga, dan tidak bisa menghabiskan banyak waktu bersama keluarga.

Berdasarkan hasil wawancara dari ketiga subjek dapat diketahui bahwa subjek $G$ dan Ro merasakan paling stres pada saat penangkapan hal ini disebabkan karena perasaan kaget dan pada saat penangkapan terjadi, ibu $\mathrm{G}$ dan Ro berada di dekat subjek. Setelah penangkapan tejadi hal yang selanjutnya membuat subjek $G$ dan Ro stres adalah masa hukuman yang harus dijalani tidak berdasarkan ekspetasi mereka yaitu lebih dari satu tahun, hal ini membuat $G$ dan Ro merasa sedih dan stres. Selanjutnya subjek 
$\mathrm{G}$ dan Ro merasa stres pada awal masuk di LPKA, hal ini disebabkan karena kedua subjek masih belum beradaptasi dengan lingkungan LPKA dan masih memikirkan kejadian yang menimpanya.

Subjek R menyatakan bahwa saat yang paling membuat stres adalah pada saat sidang penjatuhan vonis masa hukuman. Subjek merasa kaget dengan jumlah masa hukuman yang harus dijalaninya. Setelah vonis hukuman, selanjutnya yang membuat subjek merasa stres adalah pada saat subjek ditahan di Polsek, subjek merasa stres karena baru pertama kali merasakan kehidupan dalam penjara. Pada saat subjek dipindahkan ke rutan dan LPKA subjek tidak lagi merasa stres, hal ini disebabkan karena subjek sudah bisa beradaptasi dengan lingkungan penjara dan sudah ikhlas menjalani hukuman yang subjek terima.

Berdasarkan dari wawancara yang dilakukan pada ketiga subjek penelitian, ketika mengalami stres ketiga subjek mengalami beberapa perubahan diantaranya perubahan aspek fisik yaitu subjek merasakan sakit pada bagian kepalanya, aspek psikologis yaitu pikiran subjek menjadi lebih kacau, dari segi emosi yaitu subjek menjadi mudah marah, dari segi perilaku pada saat mengalami stres subjek berubah menjadi lebih pendiam daripada biasanya sehingga memilih untuk menarik diri dari lingkungan atau bersikap agresif, dan aspek sosial yaitu subjek menjadi tidak ramah terhadap orang lain dan tidak mau berinteraksi dengan orang lain.

\section{Koping Stres}

Berdasarkan hasil wawancara dengan ketiga subjek mereka mengatakan ketika mereka mengalami stres hal yang pertama kali mereka lakukan adalah menarik diri dari lingkungan, hal ini dilakukan dengan tujuan untuk menenangkan perasaan mereka. Subjek G menyatakan ketika mengalami stress, hal yang dilakukan adalah menarik diri dari lingkungan atau menjahili teman- temannya sehingga membuat perasaannya senang.

Subjek $\mathrm{R}$ mengatakan ketika mengalami stress, hal yang dilakukan adalah bersikap agresif terhadap diri sendiri dengan tujuan untuk meluapkan emosinya, tidur, nonton, dan beribadah. Sedangkan subjek Ro mengatakan ketika mengalami stress, hal yang akan dilakukan selain menarik diri dari lingkungan adalah mengajak teman-temannya mengobrol dan bercanda atau beribadah.

Menurut Pargament (1997) koping religius adalah salah satu metode koping yang menggunakan pendekatan agama dalam mengatasi permasalahan yang sedang dihadapi. Pada awalnya $\mathrm{R}$ dan Ro melakukan kegiatan ibadah (solat dan mengaji) karena kewajiban, tetapi seiring berjalannya waktu kegiatan ibadah tersebut menjadi salah satu koping stres yang efektif untuk menurunkan stres yang mereka rasakan dan menenangkan perasaan mereka. Salah satu subjek mengatakan bahwa ketika mengalami stres dan melakukan kegiatan ibadah (solat dan mengaji) maka setelah itu subjek akan merasa tenang dan tidak merasa stres lagi.

Berdasarkan hasil wawancara dan analisis data dapat disimpulkan bahwa ketiga subjek penelitian melakukan koping stres dengan menggunakan emotion focused coping, cara yang dilakukan yaitu distancing (menjauh), escape atau avoidance (melarikan diri atau menghindar), dan positive reappraisal (penilaian kembali secara positif), usaha tersebut dilakukan untuk melarikan diri, berusaha untuk tidak terlibat dan bersikap seakan tidak terjadi apa-apa. Smet (1994) menjelaskan bahwa emotion focused coping digunakan individu untuk meniadakan fakta-fakta yang tidak menyenangkan. Hal tersebut memberikan sebuah pemahaman dalam diri bahwa jika seseorang dihadapkan dengan sebuah permasalahan yang dianggap tidak mampu diselesaikan maka mengatur emosinya merupakan salah satu solusi terbaik dalam mengatasi permasalahan. Lazarus \& 
Folkman (dalam Baqutayan, 2015) menjelaskan bahwa seseorang akan menggunakan strategi emotion focused coping jika dirasa tidak mampu untuk merubah kondisi yang menimbulkan stress. Pengaturan emosi dalam diri akan memicu sebuah perilaku yang jika dilakukan dengan efektif maka akan memunculkan sebuah potensi perilaku yang mampu menerima dalam diri.

Subjek lebih nyaman menggunakan koping dengan jenis emotion focused coping, hal ini diketahui dari kegiatan yang dilakukan oleh para subjek adalah kegiatan bemain gitar, menonton tv, berkumpul bersama narapidana lain, tidur, dan beribadah. Hal-hal yang dilakukan tersebut merupakan bentuk usaha yang dilakukan subjek untuk meniadakan fakta-fakta yang tidak menyenangkan terkait dengan stresnya seperti yang dikemukakan oleh Smet (1994). Hal ini sejalan dengan penelitian yang dilakukan oleh Kesuma (2016) yang menyatakan bahwa penggunaan emotion focused coping paling sering dipakai oleh subjek. Alasannya emotion focused coping lebih efektif untuk mencegah stressor selama anak pidana berada di dalam lapas dibandingkan dengan problem focused coping. Selain itu fasilitas dan waktu untuk melakukan aktivitas emotion focused coping banyak tersedia, dan dilakukan hampir setiap hari.

Penelitian lain yang sejalan adalah penelitian yang dilakukan oleh Nagara (2017) yang menunjukkan bahwa strategi koping yang digunakan narapidana remaja di lapas anak adalah stratregi koping yang berorientasi pada emosi, pemilihan strategi koping yang berorientasi pada emosi didasarkan karena narapidana remaja ingin melupakan hukuman yang sedang terjadi.

Pemilihan strategi koping stress oleh narapidana remaja di LPKA Kelas II Kota Kendari, dipengaruhi oleh beberapa faktor seperti dukungan sarana prasarana yang ada di LPKA, seperti: masjid, televisi, dan gitar. Selain dukungan sarana dan prasarana pemilihan strategi koping stres dipengaruhi oleh dukungan sosial dari keluarga, teman, dan petugas di LPKA. Ketiga subjek penelitian mendapatkan dukungan sosial dan perhatian dari keluarganya sehingga mereka menjadi lebih mudah beradaptasi dengan lingkungan LPKA. Selain dukungan sosial dan perhatian dari keluarganya ketiga subjek, penelitian juga mendapatkan banyak informasi dari petugas mengenai keadaan lingkungan LPKA, jumlah masa hukuman dan pemotongan masa hukuman, dan mendapat bantuan dari petugas jika mengalami masalah yang mereka tidak dapat selesaikan sendiri. Selain dukungan sarana dan prasarana, dan dukungan sosial, pemilihan koping stres juga dipengaruhi oleh factor lain yaitu keterampilan subjek dalam memecahkan masalah serta keterampilan bersosialisasi dengan orang lain. Subjek tidak mengalami kesulitan dalam berkomunikasi dengan narapidana lain ketika menjalani hukuman, keterampilan bersosialisasi berkaitan dengan keterampilan dalam memecahkan masalah. Subjek mudah untuk mencari informasi mengenai keadaan di dalam LPKA, sehingga dapat dijadikan masukan untuk menghadapi masalah selama berada di dalam LPKA.

Pandangan positif yang dimiliki individu dapat menjadi faktor pendukung dalam pemilihan strategi koping, ketiga subjek memiliki pandangan positif terhadap hukuman yang harus mereka jalani sebagai hal yang membawa dampak positif serta membuat lebih dekat dengan sang pencipta. Subjek R dan Ro memiliki pandangan untuk tidak mengulangi kesalahan perbuatan dimasa lampau. 


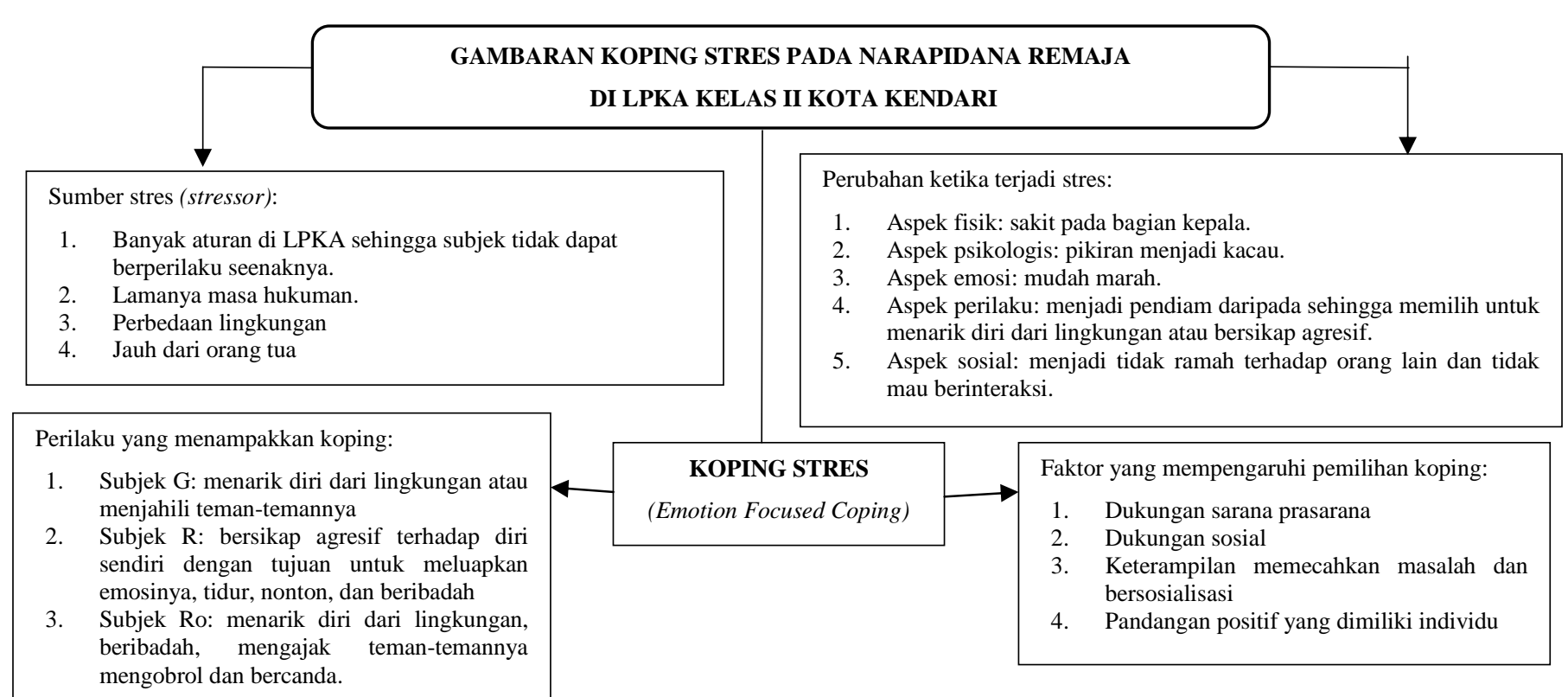

\section{Gambar 2. Gambaran Koping Stres Pada Narapidana Remaja Di LPKA Kelas II Kota Kendari}

\section{Kesimpulan dan Saran Kesimpulan}

Berdasarkan hasil penelitian dapat disimpulkan bahwa strategi koping stress yang digunakan oleh narapidana remaja di LPKA Kelas II Kota Kendari adalah strategi emotion focused coping yaitu koping yang bertujuan untuk mengatur kondisi emosi yang disebabkan oleh stres yang diperoleh melalui penghindaran terhadap stressor dan memperhatikan aspek positif dari diri dan situasi. Pemilihan emotion focused coping didasarkan karena narapidana remaja ingin melupakan hukuman yang sedang terjadi dengan melakukan berbagai kegiatan seperti bemain gitar, menonton tv, berkumpul bersama narapidana lain, tidur, dan beribadah.

Faktor yang mempengaruhi pemilihan strategi koping stres oleh narapidana remaja di LPKA Kelas II Kota Kendari adalah dukungan sosial yang diterima dari pihak keluarga, dukungan sarana prasarana yang tersedia di LPKA, ketrampilan dalam memecahkan masalah, ketrampilan dalam bersosialisasi, dan pandangan positif yang dimiliki setiap individu dalam penyelesaian masalah.

\section{Saran}

1. LPKA Kelas II Kota Kendari

Bagi pihak LPKA Kelas II Kota Kendari perlu mengembangkan keterampilan yang dapat membuat narapidana remaja untuk lebih dapat melakukan koping stress yang bersifat positif, dengan cara bekerjasama dengan berbagai pihak yang berkaitan dengan kelangsungan pendidikan narapidana remaja di dalam lapas

2. Narapidana Remaja

Narapidana remaja yang sedang menjalani hukuman di dalam LPKA perlu untuk lebih memanfaatkan kegiatan pembinaan yang dilakukan oleh pihak LPKA untuk mengurangi tekanan yang ada akibat permasalahan yang sedang terjadi.

3. Peneliti Selanjutnya

Bagi peneliti selanjutnya yang ingin meneliti kembali strategi koping stres narapidana remaja diharapkan dapat mempertimbangkan lebih lanjut 
mengenai masa hukuman informan penelitian.

\section{Daftar Pustaka}

Baqutayan, S. M. S. (2015). Stress and Coping Mechanisms: A Historical Overview. Mediterranean Journal of Social Science. Vol. 6 No. 2.

Ghufron, M. Nur dan Risnawati, Rini. (2011). Teori-Teori Psikologi. Yogyakarta: Ar-uzz Media.

Hurlock, E.B. (1999). Psikologi Perkembangan: Suatu Pendekatan Sepanjang Rentang Kehidupan (edisi kelima). Jakarta: Erlangga.

Kesuma, D. D. (2016). Stress Dan Strategi Coping Pada Anak Pidana (Studi Kasus Di Lembaga Permasyarakatan Kelas II A Samarinda). Psikoborneo. Vol. 4 No. 3.

Lubis, T. Mulya (1997). Hak Asasi Manusia dan Pembangunan. Jakarta: Yayasan Lembaga Bantuan Hukum Indonesia.

Matthieuw, M. \& Ivanoff, A. (2006). Using Stress, Appraisal, and
Coping Theories in Clinical Practice: Assessments of Coping Strategies After Disasters. Brief Treatment and Crisis Intervention. Vol. 6 No. 4.

Musradinur. (2016). Stres dan Cara Mengatasinya Dalam Perspektif Psikologi. Jurnal Edukasi. Vol. 2 No. 2.

Nagara, A. G. P. (2017). Strategi Coping Stress Pada Narapidana Remaja Di Lapas Anak Kelas IA Kutoarjo. Surakarta: Universitas Muhammadiyah Surakarta.

Pargament, Kenneth. I. (1997). The Psychology of Religion and Coping. New York: Guildford Press.

Sentana, M. A., dan Kemala, I. D. (2017) Agresivitas Dan Kontrol Diri Pada Remaja Di Banda Aceh. Jurnal Sains Psikologi. Vol. 6 No. 2.

Smet, B. (1994). Psikologi Kesehatan. Jakarta: PT. Gramedia Widia Sarana Indonesia. 